\title{
1992 - Ano de Saúde dos Trabalhadores
}

Dos vários estratos que formam uma sociedade, um deles é extremamente importante: a População Economicamente Ativa - PEA, representada pelos trabalhadores de todos os niveis. É da PEA que depende todo o restante da sociedade, ou seja, os menores de 14 anos, os maiores de 60 anos e os inválidos e incapazes física ou psiquicamente para o trabalho.

Nos paises desenvolvidos, a PEA é representada por uma fração elevada da população, podendo chegar até mesmo a mais de $70 \%$. Já nos países em desenvolvimento, o grande numero de menores de 14 anos, aliada ao número crescente de habitantes com mais de 60 anos - uma decorrência de melhores condições de Saúde Pública - fazem com que a PEA seja apenas de 30 a $40 \%$ da população geral; a esses dois grupos etários, há que se acrescentar o trabalho de menores, em número elevado nesses paises. Assim, a proteção a ser dada à PEA assume extrema importância tanto econômica como social.

Na América Latina e no Caribe, regiāo onde se encontram paises em desenvolvimento, é muito importante a existência de uma PEA mais alta, a semelhança dos paises desenvolvidos. Foi por essa razão que a Resolução 14, da XXIII Conferência Sanitária Panamericana da Organização Panamericana da Saúde (OPAS), decidiu, em 1990, que o ano de 1992 fosse, em caráter prioritário, o ANO DE SAÚDE DOS TRABALHADORES.

Para levar adiante o Programa de Saúde dos Trabalhadores para o Quatriênio 1991-1994, a OPAS criou uma Comissão cuja coordenaçāo e secretariado fícaram a cargo do renomado especialista em Saúde Ocupacional, Dr. Álvaro Durão, Assessor Regional de Saúde Ocupacional da OPAS.

A primeira reunião da citada Comissão teve lugar no dia 26 de fevereiro de 1992, em Washington, e novas reuniōes estāo previstas para breve. A seguir estão mencionadas as conclusōes e recomendações surgidas nessa primeira reunião, evidenciando o muito que ainda há para ser feito em prol da saúde global dos trabalhadores.

Inicialmente a Comissão considerou que a situação de saúde dos trabalhadores nos países da regiâo - América Latina e Caribe - pode beneficiar-se substancialmente pelo fortalecimento e melhor articulação da estrutura vigente e por uma ação mais voltada para a prevenção de infortúnios do trabalho, assim como pela cobertura dos grupos de trabalhadores mais vulneráveis e menos atendidos como crianças, mulheres, indígenas e portadores de deficiências físicas e/ou mentais.

A Comissão considerou também que os objetivos do progresso econômico somente podem ser aceitos na medida em que dirijam a sua atenção para os seres humanos e para o bem-estar social, lembrando sempre que para haver um desenvolvimento real e socialmente justo é indispensável contar com a boa saúde e o bem-estar dos trabalhadores.

Foi destacado ainda pela Comissão que existe um conhecimento das estratégias e técnicas necessárias à eliminação, à diminuição e ao controle do risco ocupacional e que a sua aplicação beneficia não somente os trabalhadores como também conduza uma sociedade equitativa, estável e produtiva.

Finalmente, a Comissão considerou que, para a América Latina e o Caribe, a saúde dos trabalhadores é um elemento estratégico da maior importância quando a meta é superar os grandes problemas que necessitam ser resolvidos para que países dessas regiōes atinjam um desenvolvimento continuado e equitativo, com a consolidaçāo dos processos democráticos apoiados em maior participação social e na inserção eficiente no contexto mundial.

Apoiados em tais consideraçōes os membros da Comissão estabeleceram que urge influenciar os governos e o poder legislativo das representações de trabalhadores, empregadores e governantes para que dêem uma prioridade especial aos programas nacionais e de cooperação internacional que visem 
à saúde dos trabalhadores, com o auxilio das universidades e outros centros de cultura. Tais programas deveriam orientar-se de acordo com os seguintes critérios:

a) toda a ênfase possivel deve ser dada à humanização do trabalho e à adaptação deste ao ser humano de acordo com a dignidade a que este tem dereito;

b) deve-se estimular o estabelecimento de normas de proteção à saúde dos trabalbadores e também a criação e informação dos recursos humanos orientados para a eliminação e/ou controle dos fatores de risco e para a manutenção de saúde e bem-estar dos trabalhadores;

c) enfatizar os direitos dos seres humanos a saúde e ao trabalho e dar apoio aos planos nacionais que visem a prevenir os danos à saúde e aos planos de higienização do meio ambiente como forma de facilitar esforços no sentido de alcançar uma democracia avançada;

d) são necessários a formulação e o fortalecimento de uma estratégia que levem à consolidação das vontades política e técnica dos altos níveis decisórios para que se reconheça a importância do progresso econômico e social e o bem-estar das nações;

e) é necessário o estabelecimento de uma programação dos mecanismos que visem incrementar a solidariedade entre os países do continente americano e a proteção da saúde dos trabalhadores.

Para concluir e tomando em consideração o que ficou acima exposto, a Comissão faz um apelo aos governantes, às instituiçōes políticas, a sociedade civil, aos líderes políticos e sociais e à comunidade internacional, em particular às dos países desenvolvidos, para que dêem o máximo da sua atenção à saúde dos trabalhadores.

Diogo Pupo Nogueira

Editor Associado da Revista de Saúde Pública

Departamento de Sauide Ambiental

Faculdade de Saúde Pública/USP 